\title{
Chikungunya Infection and The Gynecological and Obstretic Effects on Girls and Women: A Short Note
}

\author{
Maria A Grácio* and António J Santos Grácio \\ Institute of Hygiene and Tropical Medicine / New University of Lisbon, Lisbon, Portugal
}

${ }^{\star}$ Corresponding Author: Prof. Maria A Grácio, Institute of Hygiene and Tropical Medicine / New University of Lisbon, Rua da Junqueira 100, 1348-008 Lisbon, Portugal; Email: mameliahelm@ihmt.unl.pt

Received: February 15, 2019; Accepted: March 01, 2019; Published: April 20, 2019;

\section{Short Commentary}

Chikungunya virus is the causal agent of chikungunya fever, which is a vector-borne disease that was first identified in Tanzania in 1952 [1]. The term is from the Kimakonde language and means "to become contorted" [1]. Here, our objective is to alert people to chikungunya virus and its gynecological and obstetric effects on pregnancy and children. So, after general considerations on chikungunya virus we present the effects that have been considered more relevant, of chikungunya infection on girls and woman in the gynecological and obstetric context.

\section{General Considerations}

The vectors of chikungunya virus are the mosquitoes Aedes albopictus and Aedes aegypti. However, it is also possible that vertical transmission, a transmission occurs from mother- to- child during pregnancy or at birth. Accordingly [2] the chikungunya epidemic that occurred on La Reunion Island, 2005-2006, revealed for the first time the possibility of mother- to- child transmission in the perinatal period with a high rate of morbidity.

In a general context, we can show the world importance of chikungunya infection by the occurrence of outbreaks in the world [3]: (1) Sudan, 15 October 2018; (2) Mombasa - Kenya, 27 February 2018; (3) Italy, 29 September 2017; (4) Italy, 15 September 2017; (5) France, 25 August 2017; (6) Kenya, 9 August 2016; (7) United States of America, 14 June 2016; (8) Argentina, 14 March 2016; (9) Spain (update), 17 September 2015; (10) Senegal, 14 September 2015;(11) Spain, 10 August 2015; (12) France, 23 October 2014; (13) in the French part of the Caribbean isle of Saint Martin, 10 December 2013; (14) India, 17 October 2006; (15) South West Indian Ocean, 17 March 2006;(16) La Reunion Island (France), 17 February 2006.

\section{Effects of Chikungunya Infection on Girls and Woman}

The authors [4] have indicated that "in addition to virus transmission at birth, potential complications include transplacental transmission before birth, congenital malformations, stillbirths, growth restriction, and preterm delivery. The high fever that characterizes chikungunya infection could cause uterine contractions or fetal heart rate abnormalities, which might promote spontaneous or induced preterm delivery (cesarean for fetal salvage). The hemorrhagic syndrome described at the onset of infection might be manifested by vaginal bleeding during pregnancy or third-stage hemorrhaging, reported for dengue virus [5, 6]". In [7], we have a good article on "congenital and perinatal complications of chikungunya fever", which we recommend. The authors cite in their conclusion:" Chikungunya represented a substantial risk for neonates born to symptomatic parturients during the chikungunya outbreak in the Americas Region, with important clinical and public health implication."

Finally, with knowledge of the negative effects of chikungunya virus on reproductive health in girls and women the World Health Organization (WHO) [8], encourages countries to develop and maintain the capacity to detect and confirm cases, manage patients and implement social communication strategies to reduce the presence of the mosquito vectors.

Keywords: Aedes, Chikungunya, Gynecology, Obstetric, Pregnancy, Vector-Borne Diseases

\section{References}

1. WHO (April 2016) Chikungunya Fact Sheet. https://www.who.int/emergencies/ diseases/chikungunya/en/

2. Lenglet Y, Barau G, Robillard PY, Randrianaivo H, Michault A, Bouveret A, et al. Chikungunya infection in pregnancy: Evidence for intrauterine infection in pregnant women and vertical transmission in the parturient. Survey of the Reunion Island outbreak. J Gynecol Obstet Biol Reprod (Paris) 2006; 35:578-83.

3. https://www.who.int/csr/don/archive/disease/chikungunya/en/

4. Fritel X, Rollot O, Gerardin P, Gauzere BA, Bideault J, et al. (2010) Chikungunya virus infection during pregnancy, Reunion, France, 2006. Emerg Infect Dis 16: $418-425$.

5. Carles G, Talarmin A, Peneau C, Bertsch M (2000) Dengue fever and pregnancy. A study of 38 cases in French Guiana. J Gynecol Obstet Biol Reprod (Paris) 29: $758-762$.

6. Waduge R, Malavige GN, Pradeepan M, Wijeyaratne CN, Fernando S, et al. (2006) Dengue infections during pregnancy: a case series from Sri Lanka and review of the literature. J Clin Virol 37: 27-33. [crossref]

7. Torres JR, Falleiros-Arlant LH, Dueñas L, Pleitez-Navarrete J, Salgado DM, et al. (2016) Congenital and perinatal complications of chikungunia fever: a Latin American experience. Int J of Infectious Dis 51: 85-88.

8. WHO, News 12 April 2017. For more information: WHO Media Centre, email mediainquiries@who.int

Citation:

Maria A Grácio and António J Santos Grácio (2019) Chikungunya Infection and The Gynecological and Obstretic Effects on Girls and Women: A Short Note. Integr Gyn Obstet J Volume 2(2): 1-1. 